\title{
The Application of Interactive Approach to Improve Reading Proficiency of English Majors in Independent Colleges
}

\author{
Yuguang Wang \\ School of English, College of Humanities and Sciences of Northeast Normal University, \\ Changchun, 130117, China \\ xiaomi2013818@126.com
}

Keywords: interactive teaching approach, interactive reading model, teacher-student, student-student, student-text interactions.

\begin{abstract}
This paper explores the practical effects of the interactive reading teaching by taking the empirical study in two sophomore classes in the English department of College of Humanities \& Sciences of Northeast Normal University. Each class has 32 subjects respectively. The two classes were taught by the same teacher. The experiment lasted the entire semester. The only difference is that the experimental class is taught by the interactive approach, while the control class is instructed by the traditional teaching model. Through the experiment, it is concluded that the interactive approach of reading teaching can enhance the learning motivation and interests of the students. It can help the students develop good reading habits, grasp reading strategies and improve their reading ability. The interactive approach advocates the collaborative, and interactive learning which enhances their overall abilities in using English language.
\end{abstract}

\section{Introduction}

An independent college is a privately-run college which is a new form of educational organization in the process of popularization of higher education. It plays an active role in the expansion of public college enrollment. The independent college students' overall quality is generally poor. They only got average or even worse grades in English in their high school. Some students are tired of learning English. It is still hard for them to use English, although they have been studying English for six years. Aimed at the students with poor English bases and different levels in independent colleges, how to arouse their study interest and make English a competent skill for them is the difficult issue that educators of independent colleges must face. Connected with the personal teaching experiences in such colleges, the author discusses the application of the interactive approach in reading teaching in independent colleges.

\section{Literature Review}

In the early 1980s, Krashen put forward the input hypothesis. The input hypothesis emphasizes that the students' mastery of language must be through comprehensible input and the language input must be more than the current level of the individual. Then Michael Long proposed the Interaction Hypothesis, which is the expansion of Krashen's input hypothesis. Long attaches more importance to the understanding of language input than Krashen. He thinks when native speakers communicate with learners, the forms, structures and functions of language input have all changed. Native speakers constantly adjust their language forms to make them simpler and easier to understand. They make learners better understand their words by repeating, questioning and confirming, etc.

The input hypothesis emphasizes that the language of the two interactive sides must be comprehensible and plays an important role in classroom interactions. Similarly, output hypothesis is a key element in classroom interactions. According to Swain, language output can be more 
effective to promote the development of students' language competence than language input, because language output can only be made on the basis of full understanding of language input. Learners must process the form and content of output so that the output content can be expressed completely. Swain thinks that learners must use the second language in order to master it. The enthusiasm of the learners should be well aroused to realize comprehensive output. Swain's output hypothesis points out that second language acquisition is a two-way process, which needs the joint participation of the teachers and the learners. The learners are provided not only language input, but also the chances of language output.

Rumelhart (1977), a cognitive psychologist, published his paper Towards an Interactive Model of Reading, in which he proposed interactive model of reading. The model assumes that reading process is neither just bottom-up decoding nor pure top-down psychological guessing game, but a process of the comprehensive application of the two information processing models. The bottom-up model helps readers find out the new information and the information which is different from their own predictions. The top-down model helps readers decide all the possible meanings of the information according to the existing knowledge in the brain and make the reasonable choice from them.

According to Rumelhart's interactive model, reading comprehension is the interactional process of visual information and readers' prior knowledge. Readers start with the processing of visual information (bottom-up). Once words are recognized as identifiable signals, background schemata about language and common sense begin to work and carry on the explanation to information source (top-down). The two-way processing varies from person to person, which depends on readers' knowledge level, the aim and speed of reading and the contents and difficulty of reading materials. Experienced readers are able to adapt to the request of the specific discourse and reading environment and alternate two processing modes.

\section{The Analysis of Test Scores}

The experiment lasted the entire semester. the experimental class was taught according to the interactive teaching principles and the control class was instructed by the traditional teaching method. SPSS statistic software is used for the statistic analysis.

Before the experiment, the two classes are given a test of reading comprehension. The testing material includes 20 vocabulary issues, 10 phrase issues, translation, cloze and 4 passages with 5 multiple-choice questions for each passage. The total score is 100 points. The scores of the two classes are compared in the following Table.

Table 3.1 Group statistics for the pretest of the two classes

\begin{tabular}{|c|c|c|c|c|}
\hline & $\mathrm{N}$ & Mean & $\begin{array}{c}\text { Std. } \\
\text { Deviation }\end{array}$ & Std. Error Mean \\
\hline $\begin{array}{c}\text { The experimental } \\
\text { class }\end{array}$ & 32 & 59.59 & 5.967 & 1.055 \\
\hline The control class & 32 & 58.25 & 6.011 & 1.063 \\
\hline
\end{tabular}


Table 3.2 Independent samples test for the pretest of the two classes

\begin{tabular}{|c|c|c|c|c|c|c|c|c|c|}
\hline & \multicolumn{2}{|c|}{$\begin{array}{c}\text { Levene's } \\
\text { Test for } \\
\text { Equality of } \\
\text { Variances }\end{array}$} & \multicolumn{7}{|c|}{ t-test for Equality of Mean } \\
\hline & \multirow[b]{2}{*}{$\mathrm{F}$} & \multirow[b]{2}{*}{ Sig. } & \multirow[b]{2}{*}{$\mathrm{t}$} & \multirow[b]{2}{*}{$\mathrm{df}$} & \multirow{2}{*}{$\begin{array}{c}\text { Sig. } \\
\text { (2-tailed) }\end{array}$} & \multirow{2}{*}{$\begin{array}{c}\text { Mean } \\
\text { Difference }\end{array}$} & \multirow{2}{*}{$\begin{array}{c}\text { Std.Error } \\
\text { Difference }\end{array}$} & \multicolumn{2}{|c|}{$\begin{array}{l}95 \% \text { Confidence } \\
\text { Interval of the } \\
\text { Difference }\end{array}$} \\
\hline & & & & & & & & Lower & Upper \\
\hline $\begin{array}{c}\text { Equal } \\
\text { variances } \\
\text { assumed }\end{array}$ & .005 & .946 & 897 & 62 & .373 & 1.344 & 1.497 & -1.649 & 4.337 \\
\hline $\begin{array}{c}\text { Equal } \\
\text { variances not } \\
\text { assumed }\end{array}$ & & & .897 & 61.997 & .373 & 1.344 & 1.497 & -1.649 & 4.337 \\
\hline
\end{tabular}

Table 3.1 shows that the subjects in the experimental class in the pretest had a mean score of 59.59 with a standard deviation of 5.967 and the control class had a mean score of 58.22 with a standard deviation of 6.011. Table 3.2 shows the value of the significance of t-test of Equality of Means is 0.373 (>0.05). The mean scores of the two classes are almost the same, therefore, we may conclude that there is no obvious difference in the reading competence between the two groups before the experiment.

Table 3.3 Paired samples statistics for the two tests of the experimental class

\begin{tabular}{|ll|l|l|l|l|}
\hline & & Mean & $\mathrm{N}$ & Std. Derivation & Std. Error Mean \\
\hline The experimental class & pretest & 59.59 & 32 & 5.967 & 1.055 \\
& posttest & 65.75 & 32 & 7.943 & 1.404 \\
\hline
\end{tabular}

Table 3.4 Paired samples correlations for the two tests of the experimental class

\begin{tabular}{|ll|l|l|l|}
\hline & & $\mathrm{N}$ & Correlation & Sig. \\
\hline The experimental class & $\begin{array}{c}\text { pretest\&p } \\
\text { osttest }\end{array}$ & 32 & .369 & .038 \\
\hline
\end{tabular}

Table 3.5 Paired samples test for the two tests of the experimental class

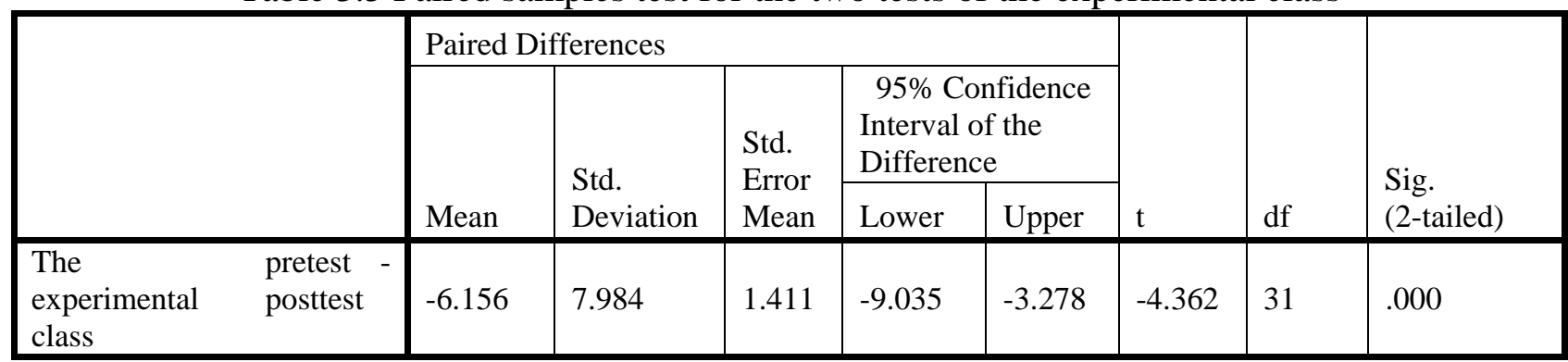

Table 3.3 shows that the mean score of pretest of the experimental class is 59.59 with a standard deviation of 5.967, and the score of posttest is 65.75 with a standard deviation of 7.943. In table 3.4, the correlation is 0.369 and the significance is 0.038 . In table 3.5 , the valve of deviation between the pretest and posttest mean scores of the experimental class is -6.156 with a standard deviation of 7.984. The value of $t$ is -4.362 . The significance (2-tailed) is 0.000 . We can say there is significant difference between the pretest and posttest in reading comprehension of the students in the experimental class. 
Table 3.6 Paired samples statistics for the two tests of the control class

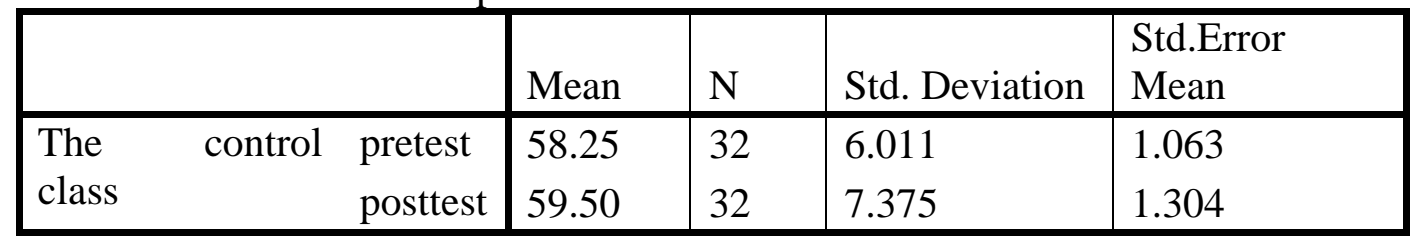

Table 3.7 Paired samples correlations for the two tests of the control class

\begin{tabular}{|c|c|c|c|c|}
\hline & & $\mathrm{N}$ & correlation & Sig. \\
\hline The control class & $\begin{array}{l}\text { Pretest } \\
\text { \&posttest }\end{array}$ & $\begin{array}{l}3 \\
2\end{array}$ & .324 & .071 \\
\hline
\end{tabular}

Table 3.8 Paired samples test for the two tests of the control class

\begin{tabular}{|c|c|c|c|c|c|c|c|c|c|}
\hline & & \multicolumn{5}{|c|}{ Paired Differences } & \multirow[b]{3}{*}{$\mathrm{t}$} & \multirow[b]{3}{*}{$\mathrm{df}$} & \multirow{3}{*}{$\begin{array}{l}\text { Sig. } \\
\text { (2-tailed) }\end{array}$} \\
\hline & & \multirow[b]{2}{*}{ Mean } & \multirow{2}{*}{$\begin{array}{l}\text { Std. } \\
\text { Deviation }\end{array}$} & \multirow{2}{*}{$\begin{array}{l}\text { Std. } \\
\text { Error } \\
\text { Mean }\end{array}$} & \multicolumn{2}{|c|}{$\begin{array}{l}\text { 95\% Confidence } \\
\text { Interval of the } \\
\text { Difference }\end{array}$} & & & \\
\hline & & & & & Lower & Upper & & & \\
\hline $\begin{array}{l}\text { The } \\
\text { Control } \\
\text { class }\end{array}$ & $\begin{array}{l}\text { pretest - } \\
\text { posttest }\end{array}$ & -1.250 & 7.862 & 1.390 & -4.084 & 1.584 & -.899 & 31 & .375 \\
\hline
\end{tabular}

From table 3.6, we can see that the mean score of pretest of the control class is 58.25 with a standard deviation of 6.011, while its mean score of pretest is 59.50 with a standard deviation of 7.375. In table 3.7, the correlation between the two mean scores of the control class is 0.324 and the significance is 0.071 . In table 3.8, it shows that the value of deviation between the pretest and posttest mean scores of the control class is -0.250 with a standard deviation of 7.862 . The value of $t$ is -0.899. The significance (2-tailed) is 0.375. It means that there is no significant difference between the pretest and posttest mean scores in reading comprehension.

Table 3.9 Group statistics for the posttest of the two classes

\begin{tabular}{|l|l|l|l|l|}
\hline & N & Mean & Std. Deviation & Std. Error Mean \\
\hline The experimental class & 32 & 65.75 & 7.943 & 1.404 \\
\hline The control class & 32 & 59.50 & 7.375 & 1.304 \\
\hline
\end{tabular}

Table 3.10 Independent samples test for the posttest of the two class

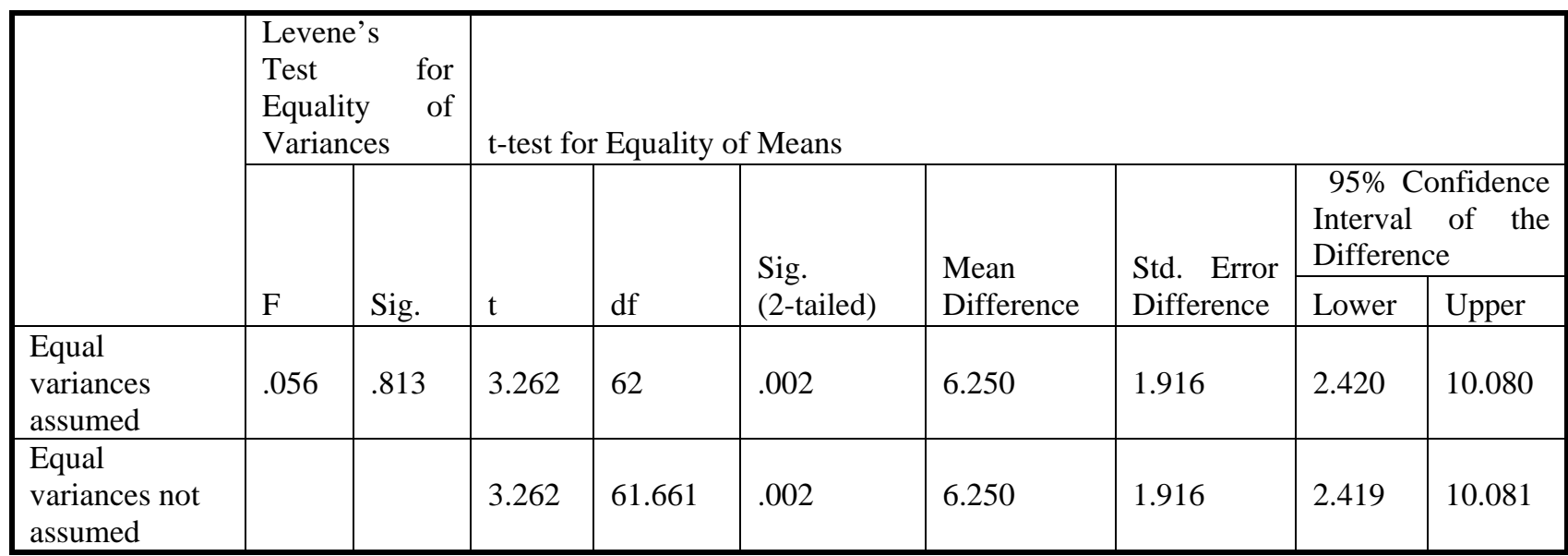

Table 3.9 shows that the subjects in the experimental class in the posttest had a mean score of 65.75 with a standard deviation of 7.943 and the control class had a mean score of 59.50 with a standard deviation of 7.375. Table 3.10 shows the value of $F$ of Levene's Test of Equality of variances is 0.056 with a significance of 0.813 . The value of $t$ is 3.262 with a significance (2-tailed) of $0.002(<0.05)$. So the mean scores of the two classes are significant different. Therefore, we may 
conclude that there is obvious difference in the reading competence between the two groups after the experiment. The reading ability of the experimental class is more improved than that of the control class.

\section{Conclusion}

This paper studies the application of the interactive approach in reading teaching and discusses the interaction between the teacher and students, among students and between the students and text. The interactive approach is based on the existing researches of reading models. The application of the interactive teaching approach is guided by the relevant interactive theories. Based on the theoretical foundation and combined with practices, this paper has presented the interactive language teaching pattern that is applied to the reading teaching of the independent colleges. This teaching model has been applied in the concrete reading teaching.

The English reading teaching should be always student-centered and teacher-guided. In the process of the interactive teaching, the teacher should be good at using the authentic language environments to create situations and make the students acquire language from the real communications. At the same time, the teacher should play a role in guiding, enlightening and monitoring in the interactions, organize the classroom teaching and guarantee the normal proceeding of teaching.

\section{References}

[1] Carrell,P.LandEisterhold.J.C. 'SchemaTheory andESLReadingPedagogy'[J].TESOL Quareterly, 1983.

[2] Ellis, R. TheStudyofSecond LanguageAcquisition[M]. Oxford University Press, 1994.

[3] Eskey, D. \& W. Grade. Interactive models for second-language reading: perspectives on interaction. In Carrel et al (ed), Interactive Approaches to Second Language Reading. Beijing: University of Cambridge press, authorized the World Book Publishing House, 2006.

[4]Krashen, S. The Input Hypothesis: Issues and Implications[M].London:Longman,1985.

[5] Long, M. H. Input, Interaction and Second Language Acquisition. In H. Winitz(Ed.), Native Language and Foreign Language Acquisition. Annals of the New York Academy of Sciences.

[6] Rumelhart, D.E. Toward an interactive model of reading. In S. Dornic(ed.) . Attention and Performance. Mahwah, NJ: Lawrence Erlbaum, 1977.

[7] Swain, M. Three Functions of Output in Second Language Learning: Principle and Practice in Applied Linguistics [M]. London: Oxford University Press, 1995. 